\title{
Deteksi Objek Terapung pada Sungai Martapura dengan Metode Haar Like Feature Menggunakan Kamera Smart Phone
}

\author{
Nahdi Saubari ${ }^{{ }^{*}}$, Rudy Ansari ${ }^{\mathrm{b}}$, Mukhaimy Gazali ${ }^{\mathrm{c}}$ \\ a,b,c Program Studi Informatika, Fakultas Teknik, Universitas Muhammadiyah Banjarmasin \\ Naskah Diterima : 14 September 2019; Diterima Publikasi : 21 Oktober 2019 \\ DOI : 10.21456/vol9iss2pp141-148
}

\begin{abstract}
Martapura river is the center of Banjarmasin's local life, especially for water transportation and its famous floating market tourism spot. Due to various floating objects in Martapura river, a method to detect those objects is needed to control the condition of the river. In general, there are several methods to detect objects such as Gaussian, Support Vector Machine (SVM), Independent Component Analysis (ICA) and the newest method called Haar Like Feature (HLF). Those first three methods often used to detect moving object, while HLF mostly used to detect human's face. This research aimed to examine the use of HLF method to detect floating objects in Martapura river by using smartphone's camera with the specification of 16Megapixel and 1080p resolution. The data collected with random sampling technique in two different spots in Banjarmasin at different times. Images and videos then examined using HLF method. The result shows that HLF method by using smartphone camera cannot be used to identify any floating objects. Detecting floating objects with HLF cannot be done with fuzzy quality of camera's pixels and resolutions.
\end{abstract}

Keywords: Haar Like Feature (HLF); Object Detection; Floating; River; Smart Phone

\begin{abstract}
Abstrak
Sungai Martapura merupakan pusat aktivitas warga kota Banjarmasin, terutama sebagai transportasi air dan wisata pasar terapung yang terkenal. Untuk membantu memantau kondisi sungai Martapura maka diperlukan suatu metode deteksi objekobjek terapung yang cenderung bergerak tersebut. Pada umumnya ada banyak metode untuk mendeteksi objek seperti Gaussian, Support Vector Machine (SVM), Independent Component Analysis (ICA) serta metode yang terbaru yaitu Haar Like Feature $(H L F)$. Ketiga metode pertama lazim digunakan untuk objek bergerak, sedangkan HLF cenderung lebih banyak digunakan untuk deteksi wajah manusia. Penelitian ini bertujuan untuk menguji penggunaan metode HLF dalam mendeteksi objek terapung pada sungai Martapura dengan menggunakan kamera smartphone yang memiliki kamera 16Megapixel dan resolusi 1080p. Pengumpulan data dilakukan dengan teknik random sampling pada dua titik di tengah kota Banjarmasin pada waktu yang berbeda-beda. Hasil berupa citra dan video kemudian diolah dengan menggunakan metode eksperimen HLF. Hasil penelitian menunjukkan bahwa penggunaan metode HLF dengan menggunakan kamera smartphone tidak dapat digunakan untuk deteksi objek terapung. Keberhasilan deteksi objek terapung dengan menggunakan metode HLF masih belum bisa menggunakan kamera dengan pixel dan resolusi yang fuzzy.
\end{abstract}

Kata kunci : Haar Like Feature (HLF); Deteksi Objek; Terapung; Sungai; Smartphone

\section{Pendahuluan}

Sungai adalah ikon yang menjadikan ibu kota Provinsi Kalimantan Selatan dijuluki Kota Seribu Sungai. Salah satu sungai yang membelah kota Banjarmasin adalah Sungai Martapura yang menampung berbagai aktivitas masyarakat kota Banjarmasin, baik itu untuk pemenuhan kebutuhan sehari-hari seperti mandi dan mencuci pakaian, transportasi air, hingga wisata pasar terapung. Berbagai aktivitas tersebut berpengaruh pada

*) Penulis korespondensi: nahdi@umbjm.ac.id banyaknya objek yang ditemui pada permukaan sungai.

Aktivitas pasar terapung misalnya, sedikit banyak berkontribusi terhadap sampah padat maupun cair yang ada di sungai. Begitu pula dengan tumbuhan air seperti enceng gondok, yang mana kehadirannya kerap mengganggu aktivitas warga, khususnya untuk transportasi air. Tak jarang adanya sampah dan enceng gondok yang mengapung dapat menghambat kelancaran sirkulasi transportasi air.

Selain itu, dengan meningkatnya beban transportasi darat, maka tidak menutup kemungkinan 
ke depannya sungai di Banjarmasin akan difungsikan kembali semaksimal mungkin sebagai transportasi air melalui program revitalisasi sungai (Abidin, 2016). Ke depannya, beban lalu lintas harian transportasi sungai akan menjadi suatu hal yang penting untuk diteliti lebih dalam terkait objek terapung yang ada di permukaannya (Hinojosa et al., 2011). Transportasi air dengan menggunakan kapal dan perahu adalah suatu hal yang menjadi bagian sehari-hari dari kehidupan masyarakat kota Banjarmasin (Abidin 2016; Rochgiyanti 2011).

Sehubungan dengan hal tersebut, maka faktor keamanan dan kebersihan sungai menjadi suatu hal yang penting. Untuk membantu memantau kondisi permukaan sungai, maka diperlukan suatu metode deteksi untuk objek terapung yang cenderung bergerak.

Pada penelitian-penelitian sebelumnya sudah ada yang mampu mendeteksi objek bergerak, namun kebanyakan menggunakan metode Gaussian (Waliulu 2018; Zhu et al., 2018; Athira et al., 2018), Support Vector Machine (SVM) (Komorkiewicz et al., 2012; Bencheriet 2018) dan Independent Component Analysis (ICA) (Déniz et al., 2003). Sedangkan berdasarkan lokasinya, tentang pendeteksian objek hanya untuk mendeteksi objek yang ada di darat (Komorkiewicz et al., 2012; Waliulu 2018), serta untuk mendeteksi objek yang ada di laut (Borghgraef et al., 2010; Hinojosa et al., 2011).

Adapun pendekatan Haar Like Feature (HLF) merupakan metode pendeteksian objek terbaru yang merupakan pengembangan dari sistem pendeteksi objek citra digital yang sebelumnya hanya mengolah gambar dengan melihat dari nilai RGB. Metode ini digunakan untuk menghasilkan deteksi objek yang memiliki kualitas visual lebih baik (Viola et al. 2005). Metode ini kerap digunakan untuk deteksi wajah (Sabuari et al., 2016), dan beberapa kali pernah digunakan untuk deteksi objek seperti plat kendaraan (Michael 2018) dan mobil yang bergerak (Moghimi et al., 2018).

Berdasarkan pertimbangan di atas, maka HLF sebagai metode deteksi objek terbaru yang memiliki kelebihan kualitas deteksi objek dengan visual yang lebih baik dipilih dalam penelitian ini untuk mendeteksi objek terapung di sungai Martapura.

Tujuan penelitian ini adalah untuk mengetahui keefektifan metode $H L F$ dalam mendeteksi objek terapung di sungai, mengingat bahwa metode ini biasanya hanya digunakan untuk deteksi wajah dan bukan pada objek secara umum.

Media yang digunakan untuk pengambilan citra adalah smartphone, sehingga harapannya hasil penelitian ini akan mudah diaplikasikan dengan gadget yang digunakan sehari-hari.

\section{Kerangka Teori}

\subsection{Deteksi Objek Bergerak dengan Computer Vision}

Terminologi lain yang berkaitan erat dengan pengolahan citra digital adalah computer vision atau machine computer. Pada hakikatnya, computer vision mencoba meniru cara kerja visual manusia (human vision). Human vision sesungguhnya sangat kompleks, manusia melihat objek dengan indera penglihatan (mata) lalu objek citra diteruskan ke otak untuk diinterpretasi sehingga manusia mengerti objek apa yang tampak dalam pandangan matanya. Prosesproses dalam computer vision dibagi dalam 3 (tiga) aktivitas :

1. Memperoleh atau mengakuisisi citra digital, proses ini bisa disebut juga sebagai proses image preprocessing.

2. Melakukan teknik komputasi untuk memproses atau memodifikasi data citra berupa pixel.

3. Menganalisis dan menginterpretasi citra menggunakan hasil pemrosesan untuk tujuan tertentu, misalnya memandu robot, mengontrol peralatan, memantau manufaktur, dan lain-lain.

Deteksi objek yang kuat dan cepat merupakan tantangan besar dalam bidang computer vision. Deteksi yang kuat dan cepat memiliki dua fitur utama yaitu eksekusi paralel hibrida dan metode skala gambar. Eksekusi paralel hibrida mengeksploitasi penggolongan struktur cascade, pengklasifikasian yang terletak pada cascade lebih sering digunakan daripada pengklasifikasian berikutnya.

\subsection{Metode-metode terdahulu untuk Deteksi Objek}

Ada beberapa metode untuk mendeteksi objek yang telah ada terlebih dahulu dan digunakan sebelum adanya metode HLF, antara lain: Metode Gaussian, Support Vector Machines (SVM), dan Independent Component Analysis (ICA), sebagaimana terlihat pada Gambar 1 di bawah ini.

Metode Gaussian merupakan metode yang mempresentasikan latar belakang secara otomatis pada setiap posisi pixel dengan mengoreksi fungsi probabilitas distribusi dari Gaussian (Athira,Vijayan and Mohan, 2018). Model parametrik yang didasarkan pada model campuran Gaussian diterapkan pada daerah warna citra yang tersegmentasi dengan memproses citra warna dengan cara yang akan mengurangi area citra yang harus dipindai (Bencheriet, 2018).

Metode ini menggunakan model latar belakang "Virtual" yang dilatih oleh urutan video alih-alih gambar bingkai pertama untuk pemodelan latar belakang. Kemudian objek latar depan diekstraksi berdasarkan klasifikasi pixel. Akhirnya, menurut metode morfologis, target bergerak yang lebih jelas dilakukan untuk mewujudkan deteksi dan pelacakan waktu nyata (Zhu et al., 2018). Beberapa penelitian dengan metode Gaussian ini dapat dijumpai pada 
objek bergerak sepeti kendaraan bermotor (Waliulu, 2018; Zhu et al., 2018).

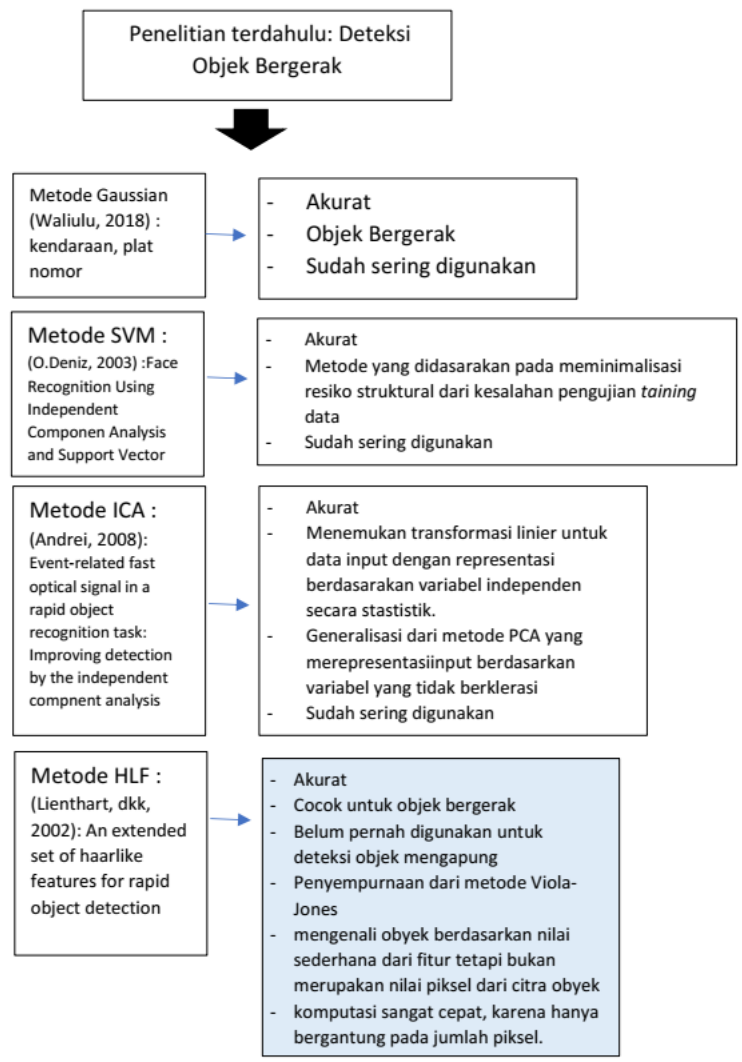

Gambar 1. Penelitian-penelitian terkait deteksi objek bergerak (Sumber : Studi Pustaka, 2019)

Metode SVM merupakan metode yang didasarkan pada meminimalisasi resiko struktural dari kesalahan pengujian training data (Déniz, Castrillón and Hernández, 2003). Klasifikasi fitur menggunakan SVM memiliki kompleksitas yang cukup tinggi dan tidak mungkin menjalankanya pada CPU secara real time ( Komorkiewicz, Kluczewski and Gorgon,2012; Al Jarouf and Kurdy, 2018; Bencheriet, 2018)

Metode ICA menemukan transformasi linier untuk data input dengan representasi berdasarkan variabel independen secara stastistik. Metode ini merupakan generalisasi dari metode PCA yang merepresentasi input berdasarkan variabel yang tidak berkolerasi (Déniz, Castrillón and Hernández, 2003).

\subsection{Metode Haar Like Feature (HLF)}

Penelitian mengenai deteksi dan pengenalan wajah teknologi computer vision telah banyak dilakukan, salah satunya adalah menggunakan HLF yang dikenal sebagai Haar Cascade Classifier. Haar-like features merupakan rectangular (persegi) features, yang memberikan indikasi secara spesifik pada sebuah gambar atau image (Michael 2018; Viola 2011; Viola et al. 2005).

Pendekatan untuk mendeteksi objek dalam gambar menggabungkan empat konsep utama, yaitu:
1. Training data.

2. Fitur segi empat sederhana yang disebut fitur Haar.

3. Integral image untuk pendeteksian fitur secara cepat.

4. Pengklasifikasi bertingkat (cascade classifier) untuk menghubungkan banyak fitur secara efisien.

\subsection{Training Data pada Haar Like Feature (HLF)}

Metode ini memerlukan 2 tipe gambar objek dalam proses training yang dilakukan (Viola et al., 2005; Viola 2011), yaitu :

1. Positive samples, berisi gambar objek yang ingin di deteksi, apabila ingin mendeteksi mata maka positive samples ini berisi gambar wajah, begitu juga objek lain yang ingin dikenali.

2. Negative samples, berisi gambar objek selain objek yang ingin dikenali, umumnya berupa gambar background (tembok, pemandangan, lantai, dan gambar lainnya). Resolusi untuk sampel negatif disarankan untuk memiliki resolusi yang sama dengan resolusi kamera. Training dari Haar menggunakan dua tipe sampel diatas. Informasi dari hasil training ini lalu dikonversi menjadi sebuah parameter model statistik.

\subsection{Sistem Kerja Algoritma Haar Cascade Classifier}

Algoritma Haar menggunakan metode statistical dalam melakukan pendeteksian wajah. Metode ini menggunakan sample HLF. Classifier ini menggunakan gambar berukuran tetap (umumnya berukuran 24x24). Cara kerja dari haar dalam mendeteksi wajah adalah dengan menggunakan teknik sliding window berukuran $24 \times 24$ pada keseluruhan gambar dan mencari apakah terdapat bagian dari gambar yang berbentuk seperti wajah atau tidak. Haar juga memiliki kemampuan untuk melakukan scaling sehingga dapat mendeteksi adanya wajah yang berukuran lebih besar ataupun lebih kecil dari gambar pada classifier (Viola et al., 2005)

Ide dari HLF adalah untuk mengenali objek berdasarkan nilai sederhana dari fitur tetapi bukan merupakan nilai pixel dari image objek tersebut. Metode ini memiliki kelebihan yaitu komputasinya sangat cepat, karena hanya bergantung pada jumlah pixel dalam persegi bukan setiap nilai pixel dari sebuah citra.

Pada dasarnya metode ini sudah pernah digunakan pada penelitian-penelitian terdahulu, namun untuk mendeteksi wajah (Sabuari et al., 2016; Deshpande et al., 2016; Déniz et al., 2003; Bencheriet 2018).

Metode HLF juga pernah digunakan untuk mendeteksi makhluk hidup yang bergerak (Uddin et $a l .$, 2015). Metode ini belum pernah digunakan untuk mendeteksi objek yang bergerak dan mengapung, akan tetapi sudah pernah teruji pada benda bergerak lainnya di darat seperti kendaraan bermotor (Moghimi et al., 2018; Hiromoto et al., 2007; Al Jarouf et al., 2018; Naba et al., 2017; Bencheriet 2018). 


\section{Metode}

Penelitian ini dimulai dengan studi literatur. Studi literatur dilakukan untuk mengumpulkan penelitianpenelitian terdahulu tentang deteksi objek bergerak yang pernah dilakukan (metode Gaussian, SVM, ICA dan Haar Like Features). Research gap yang ditemukan adalah, belum adanya penelitian terdahulu untuk mendeteksi objek bergerak yang terapung dengan menggunakan metode HLF.

Langkah selanjutnya adalah melakukan observasi lapangan dengan pengumpulan citra (terlihat pada Gambar 2) pada dua titik lokasi di pusat kota Banjarmasin yaitu di jembatan Pasar Lama dan jembatan Merdeka dengan ketinggian 5 meter dari permukaan air sungai dengan menggunakan kamera smartphone (lihat ilustrasi Gambar 3). Penggunaan smartphone dipilih dengan pertimbangan kepraktisan penggunaan media pada saat observasi.

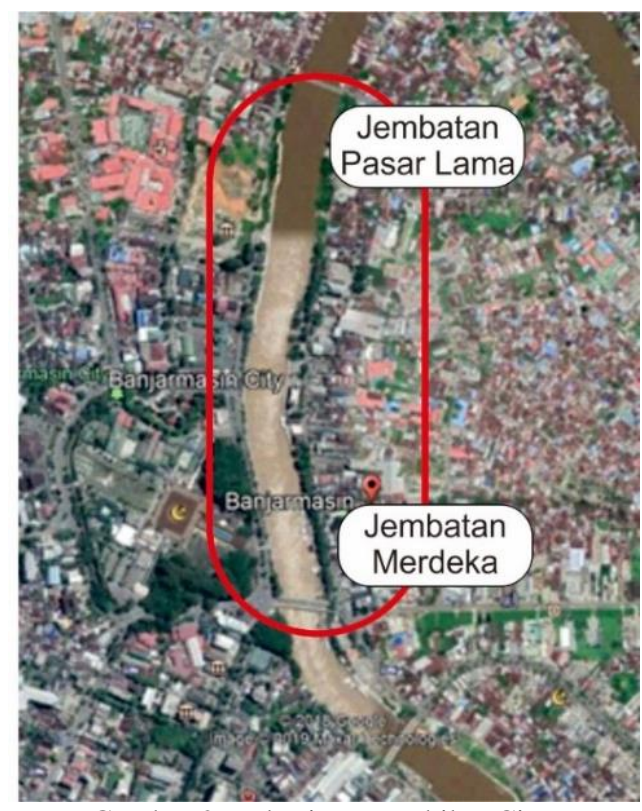

Gambar 2. Lokasi Pengambilan Citra

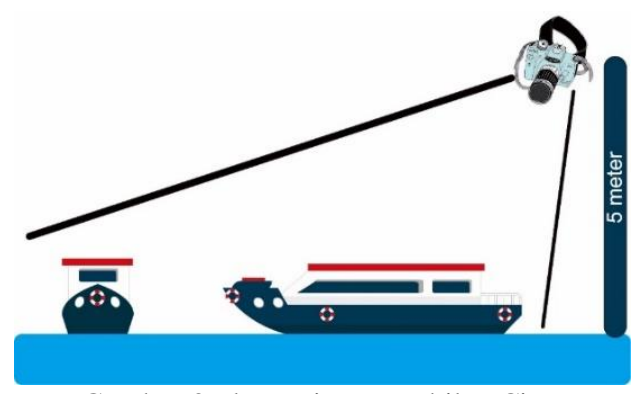

Gambar 3. Ilustrasi pengambilan Citra

Smartphone yang digunakan adalah Realme 3 Pro yang memiliki 16 Megapixel, resolusi 720x480 pixel dan 1920x1080 pixel. Kedua resolusi ini dipilih dengan pertimbangan output hasil video yang berkualitas, karena jumlah pixel yang dihasilkan sangat banyak. Jumlah pixel berpengaruh pada hasil deteksi objek.

Teknik pengumpulan data menggunakan random sampling, mengingat penelitian ini adalah penelitian dasar/pendahuluan difokuskan pada 2 waktu yang berbeda yaitu pukul 09.00-10.00 WITA dan pukul 14.00-15.00 WITA, selama 2 hari dalam seminggu 2 bulan berturut-turut pada bulan Juni dan Juli 2019. Waktu pengumpulan data ini berdasarkan pada observasi terdahulu yang menunjukkan bahwa pukul 09.00-10.00 WITA dan 14.00-15.00 WITA setiap harinya merupakan waktu puncak meningkatnya aktivitas di sungai Martapura. Hari Selasa dan Sabtu (2 hari dalam seminggu) dipilih untuk mewakili sampel hari normal dan weekend. Bulan Juni dan Juli dipilih dengan pertimbangan sebagai perpindahan musim penghujan ke kemarau.

Pertimbangan menggunakan smartphone adalah untuk melakukan eksperimen pengumpulan data dengan menggunakan media yang dapat ditemui sehari-hari, mengingat metode HLF cukup bergantung pada kualitas citra objek yang akan dideteksi.

Teknik analisis yang digunakan adalah metode HLF untuk mendeteksi objek terapung yang ada di sungai Martapura.

Pada penelitian ini, deteksi objek di sungai Martapura pada video yang awalnya merupakan citra berwarna akan dirubah menjadi citra keabu-abuan lalu citra tersebut akan dipisahkan antara latar belakang dan objek yang akan dideteksi (threshold). Proses selanjutnya adalah citra akan dideteksi menggunakan metode HLF yang sebelumnya dilatih menggunakan library dari open $c v$ terlebih dahulu. Diagram proses pendeteksian citra dengan HLF dapat dilihat pada Gambar 4.

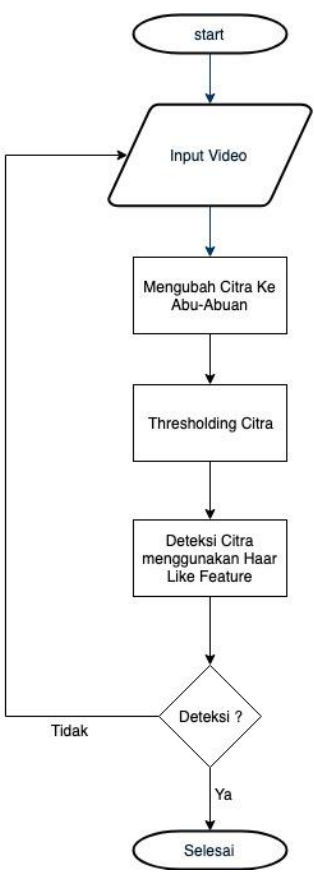

Gambar 4. Diagram proses Pengambilan Citra (Sumber : Hasil analisis, 2019) 


\section{Hasil dan Pembahasan}

Hasil observasi lapangan berupa data video dan gambar yang berhasil dikumpulkan ditunjukkan pada Tabel 1 berikut ini.

$\underline{\text { Tabel 1. Data survey lapangan berupa video Juni-Juli } 2019}$

\begin{tabular}{cccc}
\hline Hari ke & Jam & Lokasi & Jumlah objek \\
& & & 20 \\
\hline 1 & $09.00-10.00$ & Pasar Lama & 25 \\
3 & $14.00-15.00$ & Pasar Lama & 19 \\
4 & $09.00-10.00$ & Pasar Lama & 26 \\
5 & $14.00-15.00$ & Pasar Lama & 21 \\
6 & $09.00-10.00$ & Pasar Lama & 25 \\
7 & $14.00-15.00$ & Pasar Lama & 20 \\
8 & $14.09-00-10.00$ & Pasar Lama & 27 \\
9 & $09.00-15.00$ & Pasar Lama & 20 \\
10 & $14.00-15.00$ & Merdeka & 26 \\
11 & $09.00-10.00$ & Merdeka & 18 \\
12 & $14.00-15.00$ & Merdeka & 25 \\
13 & $09.00-10.00$ & Merdeka & 19 \\
14 & $14.00-15.00$ & Merdeka & 25 \\
15 & $09.00-10.00$ & Merdeka & 20 \\
16 & $14.00-15.00$ & Merdeka & 26
\end{tabular}

Dari data terlihat bahwa objek terapung pada sungai Martapura memiliki jumlah yang bervariasi pada kedua waktu yang berbeda. Kedua waktu penelitian (09.00-10.00 WITA dan 14.00-15.00 WITA) ternyata didominasi oleh alat transportasi air. Tidak terlihat adanya objek lain seperti sampah maupun tanaman air pada permukaan sungai Martapura. Hal ini disebabkan adanya kapal pembersih sungai dari Pemerintah Kota Banjarmasin yang beroperasi setiap harinya untuk membersihkan sungai Martapura dari berbagai sampah maupun tanaman air seperti enceng gondok yang dapat membahayakan jalur transportasi pada sungai.

Observasi yang dilakukan selama 2 bulan berturutturut setiap minggunya menunjukkan bahwa rata-rata objek terapung yang lewat adalah sebanyak 23 kapal/jam. Pengumpulan data yang dilakukan secara manual inilah yang diharapkan dapat dipermudah dengan menggunakan metode HLF dengan menggunakan citra dari smartphone.

Pada hasil pengujian, didapatkan data yang dibagi menjadi 2 kondisi yaitu pukul 09.00-10.00 WITA dan 14.00-15.00 WITA. Tiap kondisi dipisahkan lagi dengan durasi pengambilan video tersebut yaitu durasi 30 detik, satu menit dan dua menit. Tabel 2 menunjukkan hasil dari eksperimen data citra dan waktu rata-rata memiliki jumlah frame yang sama dikarenakan pengambilan menggunakan satu alat, yaitu kamera smartphone Real me 3 Pro.

Durasi waktu dibagi menjadi 3 segmen waktu, yaitu 30 detik, 60 detik dan 120 detik. Pemilihan durasi waktu ini berdasarkan pada kuantitas atau banyaknya objek terapung yang melewati kamera smartphone. Objek terapung yang lewat rata-rata merupakan moda transportasi air berupa kapal dan perahu kecil.
Tabel 2. Eksperimen data citra (Sumber: Hasil analisis, 2019)

\begin{tabular}{cclc}
\hline Kondisi & Waktu & \multicolumn{1}{c}{ Durasi } & $\begin{array}{c}\text { Jumlah } \\
\text { Frame }\end{array}$ \\
\hline 1 & & & 719 \\
& $09.00-$ & 30 Detik/Video & 1438 \\
& 10.00 & 60 Detik/Video & 2876 \\
\hline 2 & & 120 Detik/Video & 719 \\
& $14.00-$ & 30 Detik/Video & 1438 \\
& 15.00 & 60 Detik/Video & 2876 \\
\hline
\end{tabular}

Pada kondisi 1 dan 2 sebagaimana telah ditunjukkan pada Tabel 2, durasi video pada 30 detik memiliki frame sebanyak 719, sedangkan pada 60 detik jumlah frame adalah 1438, dan 120 detik memiliki frame sebanyak 2876. Per durasi waktu, ratarata ada beberapa objek terapung yang lewat, semakin lama durasi waktu yang digunakan, semakin banyak pula data objek terapung yang bisa terekam. Setelah pembagian frame, metode berikutnya adalah mendeteksi objek terapung tersebut dengan metode HLF.

\subsection{Eksperimen Objek Terdeteksi}

Proses pendeteksian citra dimulai dengan memasukkan video yang sudah diambil di tempat lokasi penelitian lalu proses pertama yang dilakukan adalah mengubah citra yang semula RGB menjadi keabu-abuan guna mendapatkan nilai batas yang akan digunakan untuk proses selanjutnya., lalu proses terakhir sebelum melakukan deteksi adalah proses threshold (proses mendapatkan nilai ambang dari citra keabu-abuan). Proses ini memungkinkan untuk metode HLF karena pada bagian citra yang sudah melalui proses treshold, maka objek akan terpisah dengan latar belakang pada sebuah citra.

Data yang diambil menunjukkan objek kapal yang diambil citranya berada pada sungai yang arusnya relatif tidak terlalu deras. Hal ini menjadikan citra objek terapung yang diambil pun cenderung tidak terlalu banyak bergerak dan cenderung stabil. Cepat atau lambatnya objek yang bergerak, berpengaruh terhadap kualitas data citra yang didapatkan.

Seperti terlihat pada Gambar 5, langkah-langkah yang dilakukan dimulai dengan mengubah citra yang tadinya berwarna dalam format RGB menjadi keabuabuan (Gambar 5b). Langkah selanjutnya ada gambar 5.e yaitu threshold, di mana citra abu-abu berubah menjadi citra biner, di mana nilai citra biner hanya 0 dan 1 .

Apabila latar belakang citra dan objek terpisah, maka terlihat perbedaan jelas warna hitam dan putih yang kontras. Setelah itu akan diketahui apakah objek bisa terdeteksi atau tidak. Apabila threshold berjalan dengan baik, maka objek akan dapat terdeteksi dan diberikan segmentasi citra berwarna kuning. Seperti terlihat pada Gambar 5 (c), proses threshold pada citra hasil dari kamera smartphone Realme 3 pro ternyata tidak berjalan dengan baik, di mana dapat terlihat 
bahwa antara latar belakang dan objek masih belum jelas terpisah warna hitam dan putihnya.

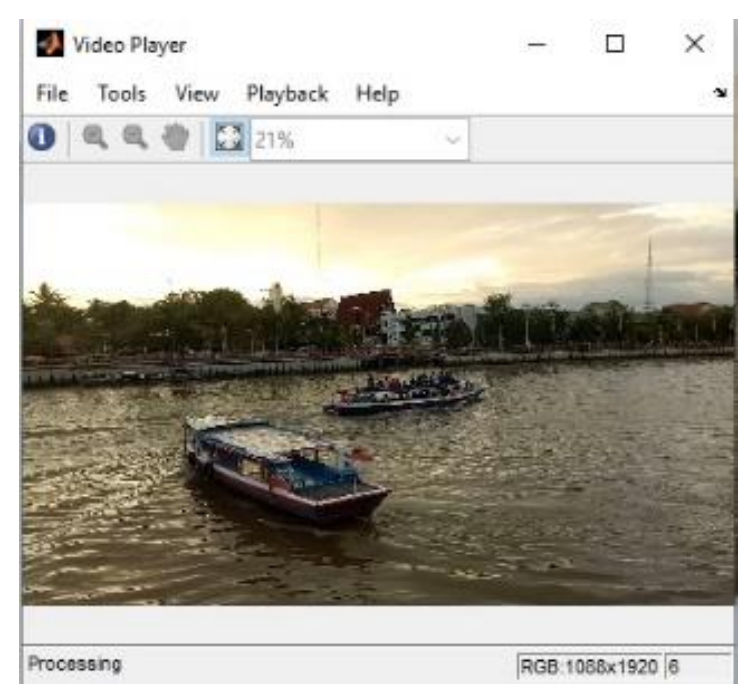

(a)

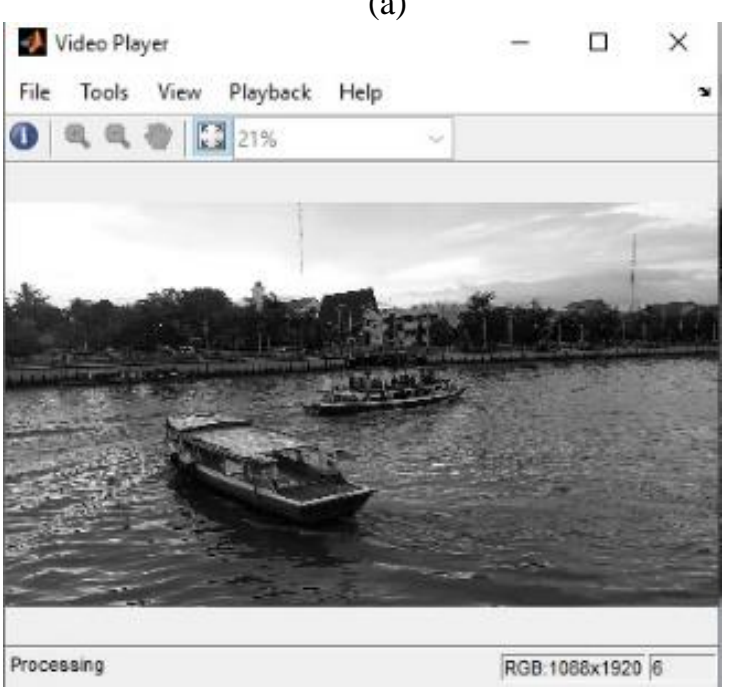

(b)

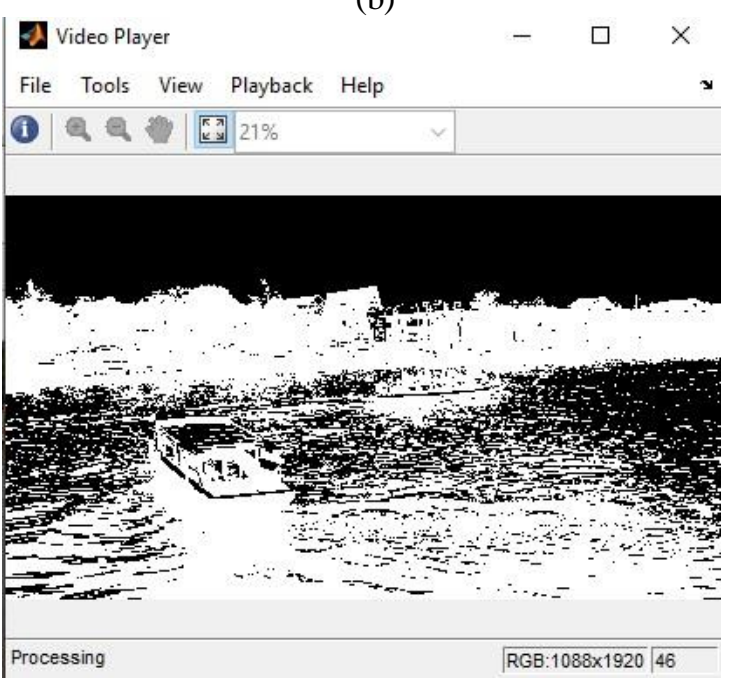

(c)

Gambar 5. (a) Citra awal (b) Citra keabu-abuan (c)Threshold
Hasil analisis pada Tabel 3, menunjukkan metode HLF tidak bisa mendeteksi objek yang mengapung di sungai menggunakan smartphone Realme dengan kamera 16 Megapixel. Pada kondisi 1, rata-rata jumlah kapal yang lewat adalah sebanyak 3 kapal dan tingkat akurasi pendeteksian sebanyak 0\%. Pada kondisi 2, rata-rata jumlah kapal yang lewat adalah sebanyak 3 kapal dengan akurasi $0 \%$. Hal ini menunjukkan bahwa pada 3 durasi yang berbeda (30 detik/video, 60 detik/video, dan $120 \mathrm{detik} / \mathrm{video}$ ), durasi pengambilan image tidak berpengaruh terhadap pendeteksian objek.

Tabel 3. Hasil pengujian citra dengan HLF (Sumber: Analisa

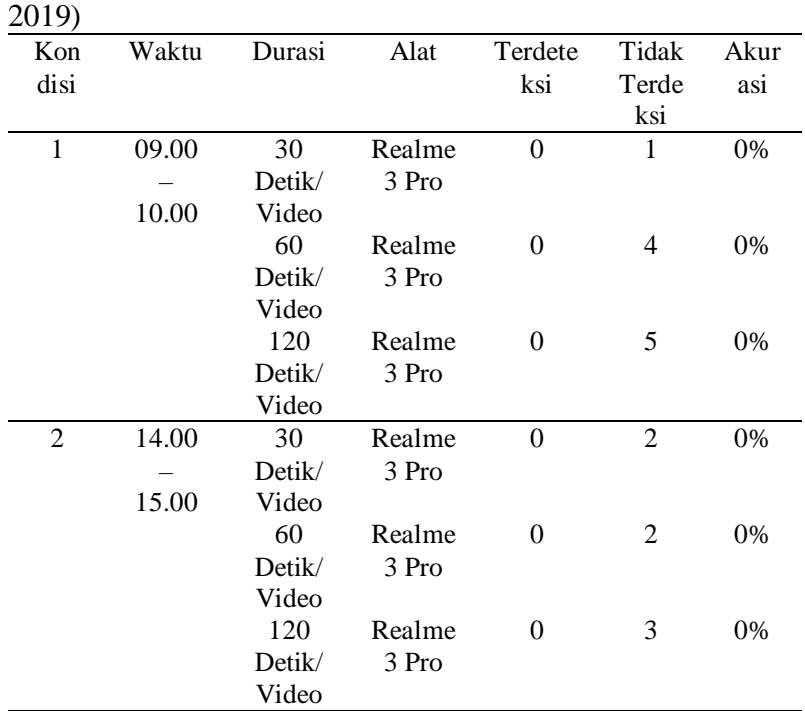

Dari 16 data citra yang didapatkan, tidak ada satupun objek terapung pada sungai Martapura yang dapat dideteksi. Terlihat pada Tabel 4, bahwa persentase keberhasilan deteksi objek terapung dengan menggunakan kamera smartphone adalah sebanyak $0 \%$.

\subsection{Faktor Eksternal yang Berpengaruh pada Citra}

Kondisi cuaca pada saat pengambilan citra cenderung berawan sehingga berpengaruh terhadap pencahayaan, bayangan, dan warna pada objek yang diteliti. Meskipun kamera smartphone yang digunakan sudah menggunakan kamera dengan spesifikasi 16 Megapixel, ternyata tidak mampu menghasilkan citra yang dapat digunakan untuk mendeteksi objek terapung. Hasil pengujian citra dengan HLF sesuai yang tertera pada Tabel 4 . 
Tabel 4. Hasil pengujian citra dengan HLF (Sumber: Analisa 2019)

\begin{tabular}{|c|c|c|c|c|c|}
\hline $\begin{array}{l}\text { Har } \\
\text { i ke }\end{array}$ & Jam & Lokasi & $\begin{array}{l}\text { Jumlah } \\
\text { Objek }\end{array}$ & $\begin{array}{l}\text { Persenta } \\
\text { se } \\
\text { Keberha } \\
\text { silan } \\
\text { Deteksi } \\
\text { Objek }\end{array}$ & $\underset{\mathrm{n}}{\text { Kesimpula }}$ \\
\hline 1 & $\begin{array}{c}09.00- \\
10.00\end{array}$ & $\begin{array}{l}\text { Pasar } \\
\text { Lama }\end{array}$ & 20 & $0 \%$ & GAGAL \\
\hline 2 & $\begin{array}{c}14.00- \\
15.00\end{array}$ & $\begin{array}{l}\text { Pasar } \\
\text { Lama }\end{array}$ & 25 & $0 \%$ & GAGAL \\
\hline 3 & $\begin{array}{c}09.00- \\
10.00\end{array}$ & $\begin{array}{l}\text { Pasar } \\
\text { Lama }\end{array}$ & 19 & $0 \%$ & GAGAL \\
\hline 4 & $\begin{array}{c}14.00- \\
15.00\end{array}$ & $\begin{array}{l}\text { Pasar } \\
\text { Lama }\end{array}$ & 26 & $0 \%$ & GAGAL \\
\hline 5 & $\begin{array}{c}09.00- \\
10.00\end{array}$ & $\begin{array}{l}\text { Pasar } \\
\text { Lama }\end{array}$ & 21 & $0 \%$ & GAGAL \\
\hline 6 & $\begin{array}{c}14.00- \\
15.00\end{array}$ & $\begin{array}{l}\text { Pasar } \\
\text { Lama }\end{array}$ & 25 & $0 \%$ & GAGAL \\
\hline 7 & $\begin{array}{c}09.00- \\
10.00\end{array}$ & $\begin{array}{l}\text { Pasar } \\
\text { Lama }\end{array}$ & 20 & $0 \%$ & GAGAL \\
\hline 8 & $\begin{array}{c}14.00- \\
15.00\end{array}$ & $\begin{array}{l}\text { Pasar } \\
\text { Lama }\end{array}$ & 27 & $0 \%$ & GAGAL \\
\hline 9 & $\begin{array}{c}09.00- \\
10.00\end{array}$ & Merdeka & 20 & $0 \%$ & GAGAL \\
\hline 10 & $\begin{array}{c}14.00- \\
15.00\end{array}$ & Merdeka & 26 & $0 \%$ & GAGAL \\
\hline 11 & $\begin{array}{c}09.00- \\
10.00\end{array}$ & Merdeka & 18 & $0 \%$ & GAGAL \\
\hline 12 & $\begin{array}{c}14.00- \\
15.00\end{array}$ & Merdeka & 25 & $0 \%$ & GAGAL \\
\hline 13 & $\begin{array}{c}09.00- \\
10.00\end{array}$ & Merdeka & 19 & $0 \%$ & GAGAL \\
\hline 14 & $\begin{array}{c}14.00- \\
15.00\end{array}$ & Merdeka & 25 & $0 \%$ & GAGAL \\
\hline 15 & $\begin{array}{c}09.00- \\
10.00\end{array}$ & Merdeka & 20 & $0 \%$ & GAGAL \\
\hline 16 & $\begin{array}{c}14.00- \\
15.00\end{array}$ & Merdeka & 26 & $0 \%$ & GAGAL \\
\hline \multicolumn{3}{|c|}{ Persentase Keberhasilan } & & $0 / 16=0 \%$ & \\
\hline
\end{tabular}

\section{Kesimpulan}

Pendeteksian citra objek terapung pada sungai Martapura dengan menggunakan metode HLF pada citra hasil kamera smartphone tidak berhasil dilakukan. Semua citra video dari kamera smartphone Realme 3 pro tidak bisa terdeteksi oleh metode $H L F$ dikarenakan proses prapengolahan citra video dari kamera smartphone Realme 3 pro pada threshold tidak bisa memisahkan antara objek dan latar belakang dengan baik.

Untuk penelitian lanjutan, data gambar dan video yang diperoleh dengan menggunakan kamera smartphone ini akan dibandingkan dengan data citra yang dikumpulkan dengan menggunakan kamera mirrorless/DSLR atapun kamera smartphone lainnya yang memiliki kualitas pixel lebih baik.

\section{Ucapan Terima Kasih}

Tim Peneliti mengucapkan terima kasih kepada Kementrian Riset, Teknologi dan Pendidikan Tinggi Republik Indonesia yang telah mendanai penelitian ini, di mana termasuk dalam skema hibah penelitan dosen pemula (PDP) tahun pelaksanaan 2019.

\section{Daftar Pustaka}

Abidin, Z., 2016. Studi Revitalisasi Angkutan Sungai Sebagai Moda Transportasi Perkotaan di Kota Banjarmasin. AGREGAT 1(2).

Athira, A.P., Vijayan, M., \& Mohan, R., 2018. Industry Interactive Innovations in Science,
Engineering and Technology. 11: p.367-376. Available at: http://link.springer.com/ 10.1007/978-981-10-3953-9.

Bencheriet, C.E., 2018. New face features to detect multiple faces in complex background. Evolving Systems 0(0): p.0. Available at: http://dx.doi.org/10.1007/s12530-017-9211-y.

Borghgraef, A., Barnich, O., Lapierre, F., Droogenbroeck, Philips, W., Acheroy, M., 2010. An evaluation of pixel-based methods for the detection of floating objects on the sea surface. Eurasip Journal on Advances in Signal Processing 2010(May 2014).

Déniz, O., Castrillón, M., and Hernández, M., 2003. Face recognition using independent component analysis and support vector machines. Pattern Recognition Letters 24(13): p.2153-2157.

Deshpande, A., Dashpute, P., Chaudhary, S., and Wankhade, S.B. 2016. Face Detection for Authentication using Haar Classifiers. 6(2): p.527-529.

Hinojosa, I.A., Rivadeneira, M.M. and Thiel, M., 2011. Temporal and spatial distribution of floating objects in coastal waters of central-southern Chile and Patagonian fjords. Continental Shelf Research 31(3-4): p. 172-186.

Hiromoto, M., Nakahara, K., Sugano, H., Nakamura, Y. and Miyamoto, R., 2007. A specialized processor suitable for AdaBoost-based detection with haar-like features. Proceedings of the IEEE Computer Society Conference on Computer Vision and Pattern Recognition.

Al Jarouf, Y.A., and Kurdy, M.B., 2018. A Hybrid Method to Detect and Verify Vehicle Crash with Haar-Like Features and SVM over the Web. 2018 International Conference on Computer and Applications, ICCA 2018: p.177-182.

Komorkiewicz, M., Kluczewski, M. and Gorgon, M. 2012. Floating point HOG implementation for real-time multiple object detection. Proceedings 22nd International Conference on Field Programmable Logic and Applications, FPL 2012: p.711-714.

Michael, A., 2018. Pengenalan Plat Kendaraan Berbasis Android menggunakan Viola Jones dan Kohonen Neural Network. ILKOM Jurnal Ilmiah 8(2): p.95.

Moghimi, M.M., Nayeri, M., Pourahmadi, M. and Moghimi, M.K., 2018. Moving Vehicle Detection Using AdaBoost and Haar-Like Feature in Surveillance Videos. Available at: http://arxiv.org/abs/1801.01698.

Naba, A., Pratama, B.M., Nadhir, A. and Harsono, H. 2017. Haar-like feature based real-time neuro car detection system. Proceeding-2016 International Seminar on Sensors, Instrumentation, Measurement and Metrology, ISSIMM 2016: p.67-70.

Rochgiyanti, 2011. Fungsi sungai bagi masyarakat di 
Tepian Sungai Kuin Kota Banjarmasin. Jurnal Komunitas 3(1): p.51-59.

Sabuari, N., Isnanto, R. and Adi, K. 2016. Jaringan Syaraf Tiruan Perambatan Balik Untuk Pengenalan Wajah. Jurnal Sistem Informasi Bisnis 6(1): p.30.

Uddin, M.S. and Akhi, A.Y. 2015. Horse Detection Using Haar Like Features. International Journal of Computer Theory and Engineering 8(5): p.415418.

Viola, P. and Jones, M. 2005. Rapid object detection using a boosted cascade of simple features. In Computer Society Conference on Computer Vision and Pattern Recognition, I-511-I-518.
Waliulu, R.F., 2018. Deteksi dan Penggolongan Kendaraan dengan Kalman Filter dan Model Gaussian di Jalan Tol. Jurnal Sistem Informasi Bisnis 8(1): p.1.

Zhu, S.,Gao, X., Wau, H.,Xu, G., Xie., Q., Yang, S., 2018. Moving object real-time detection and tracking method based on improved Gaussian mixture model. Proceedings of 2018 IEEE 7th Data Driven Control and Learning Systems Conference, DDCLS 2018 (1): p.654-658. 